Brit. J. industr. Med., 1950, 7, 12-16.

\title{
THE FATE OF SILICEOUS DUSTS IN THE BODY \\ I. A COMPARISON OF THE IN VIVO SOLUBILITIES OF CEMENT, CARBORUNDUM, QUARTZ, AND MOULDING SAND
}

BY

\author{
P. F. HOLT \\ From The University, Reading
}

(RECEIVED FOR PUBLICATION AUgust 25, 1949)

\section{Introduction}

The pulmonary lesions found in silicosis were formerly thought to be due to the abrasive nature or spiked shape of the inhaled dust particles, but this theory was questioned by Gardner (1923), who demonstrated that carborundum dust is harmless. The later work of Kettle (1932) and of Denny and others (1937) was interpreted as showing that the tissue damage is due to silicic acid formed by the solvent action of the plasma on dust. Solubility determinations by many workers, including Briscoe and others (1937), Emmons and Wilcox (1937), King and McGeorge (1938) and Whitehouse (1938) appeared to show that, in general, the dusts from which more silica dissolves are those most likely to produce fibrosis; but a detailed study of the solubility in vitro of cement and flint dusts (Holt and Briscoe, 1949) emphasized the difficulty of deducing the fate of mineral particles which enter the body from solubility data obtained under fixed and arbitrary conditions. Cement dust is of particular interest in that, although the atmospheric dust concentration is usually far higher in works where it is manufactured or handled than in places where materials give rise to dusts producing silicosis, if cement produces pulmonary lesions they are comparatively benign. Experiments previously described (Holt and Briscoe, 1949) have shown that cement has a very low silica solubility when extracted with water but that the solubility is greatly increased by traces of carbon dioxide.

In the present work the solubilities of dusts in vivo have been studied by determining the silica excreted in the urine after the administration of dust samples. This assumption that dissolved silica is completely excreted is substantially but perhaps not entirely correct (King and others, 1933).

The administration of dusts by inhalation is imjracticable for the present purpose both because it is impossible to transfer a dust sample quantitatively to the lung and also because inhaled dust is partly removed by the cilia and eventually reaches the alimentary tract. Whitehouse (1937) in a study of the effect on silica excretion of the oral administration of dusts in man found that, although finely powdered quartz and flint gave no significant increase in silica excretion, Scotch whinstone increased the output by about $30 \mathrm{mg}$. and flint of

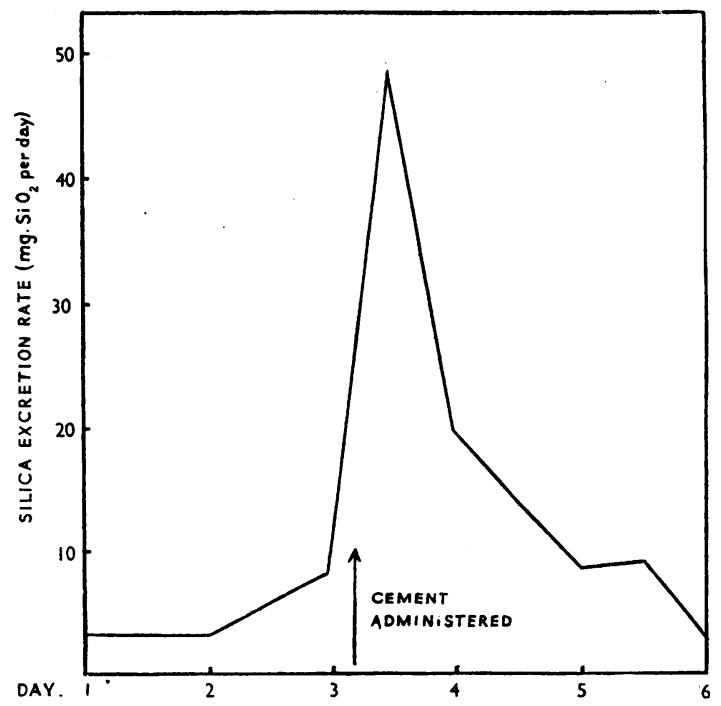

FIG. 1.-Effect of cement, orally administered, on urinary silica excretion.

particle size below $1 \mu$ by about $15 \mathrm{mg}$. Cement produces much greater increases, as is indicated in Fig. 1, in which are shown analytical data relating to urine specimens taken before and after the oral administration to a human subject of $3 \mathrm{~g}$. of cement. An increase in silica excretion after the inhalation of cement would not necessarily be due, therefore, to solution of the dust in the lung. 
TABLE 1

BXCRETION OF SILICA BEFORE AND AFTER THE INTRAPERITONEAL INJECTION OF DUSTS INTO MICE

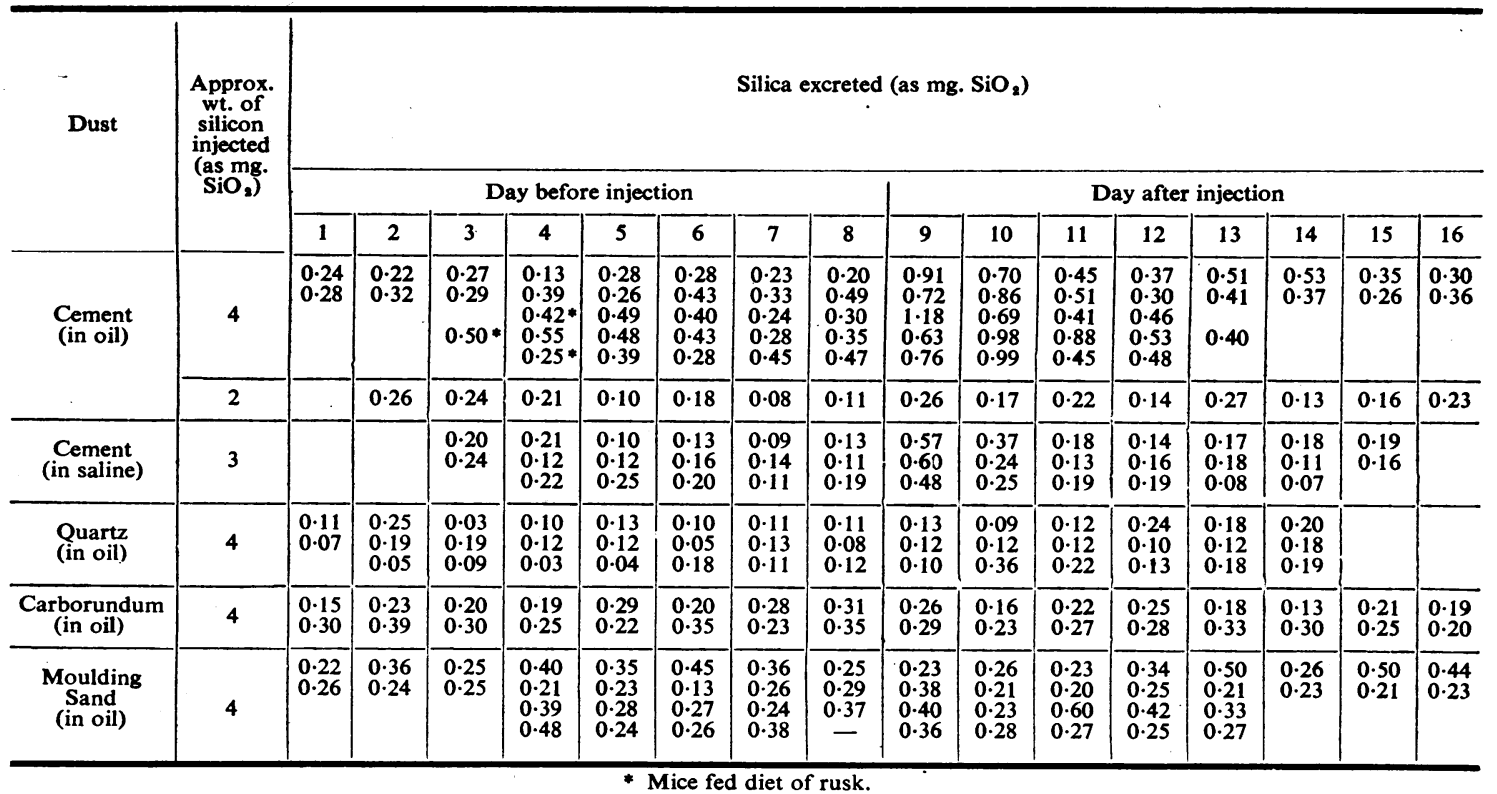

In this study, dust suspensions were injected into mice intraperitoneally and the solubility was followed both by determining the silica excreted in the urine and by analysing certain organs to which the dust might be carried by phagocytes.

Cement from the air of the crushing shed in a cement works, moulding sand from the air of an iron foundry near the sand preparation plant, quartz dust produced in a rubber-lined tumbling box from lumps of Rand quartz rock and carborundum dust separated from carborundum powder by a commercial type elutriator were compared in parallel experiments. Microscopic examination showed that the dusts consisted mainly of particles smaller than $10 \mu$ but that a few larger particles up to $25 \mu$ were present. With the exception of the carborundum, which was collected in a bag-type commercial filter, dusts were collected in a labyrinth (Briscoe and others, 1937) which separates the dust by utilizing eddy currents produced when air is drawn over a series of baffles; thus the dust was obtained without treatment by solvents.

\section{Methods}

Each animal was kept in a metabolism cage of 30-mesh stainless steel gauze under which was placed a sheet of filter paper (Whatman No. 40) to collect the urine specimen uncontaminated by freces. A sheet of "Perspex" below the cage was held by springs to the "Perspex" top and flattened the paper against the gauze. Filter papers were removed and replaced daily, and before analysis food dust was brushed from the papers. All mice were given a daily diet of $4 \mathrm{~g}$. rat cake during and for some days before the experimental period to ensure a constant dietary intake of silica, except in the initial experiments when $5 \mathrm{~g}$. of rusk and $2 \mathrm{~g}$. of fat were given daily. This latter diet was abandoned because it gave high silica excretion values (Table 1).

To avoid altering the composition or the surface condition of the dusts they were not sterilized before injection. Cement dust, because of its alkalinity and high calcium content, considerably affects the animals when injected in aqueous suspension, and for this reason all dusts were injected in arachis oil suspension to retard the initial action of the tissue fluids. However, to meet possible criticism that the oil might affect the solubility of the alkaline dust by saponification, additional experiments were carried out in which smaller amounts of cement were injected in saline suspension.

After intraperitoneal injection some of the dust which is not removed by phagocytes or by solution is found adhering to the peritoneum. Particles which are removed by phagocytes may be found in the abdominal lymph glands, the liver, and the spleen. These organs, together with the kidneys, were removed for analysis. In the initial experiments Pontamine Sky Blue was injected intraperitoneally some days before the mice were killed to facilitate the dissection of the lymph glands, but after some experience the glands were easily found without staining. The paraaortic, iliac, and mesenteric glands were removed.

The silica was determined in the papers and tissues by the colorimetric phosphomolybdate method after ashing and precipitating iron and phosphate (King, 1939). 


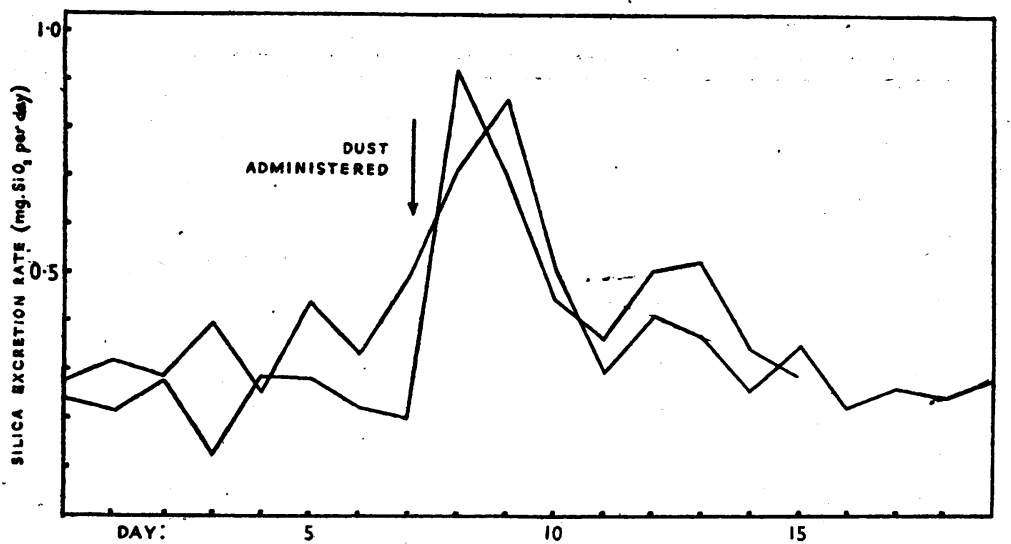

Fig. 2.-Effect of cement, injected in oil suspension, on urinary silica excretion.

\section{Results}

Excretion of Silica in the Urine.-Urinary silica values before and after the injection of the several dusts are shown in Table 1. After the injection

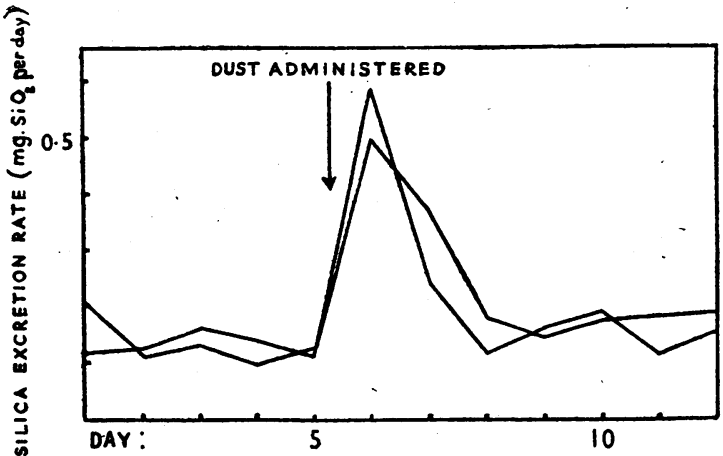

FIG. 3.-Effect of cement, injected in aqueous suspension, on urinary silica excretion.

of cement dust in quantities equivalent to about $4 \mathrm{mg} . \mathrm{SiO}_{2}$, the rate of silica excretion rose sharply within twenty-four hours and returned almost to

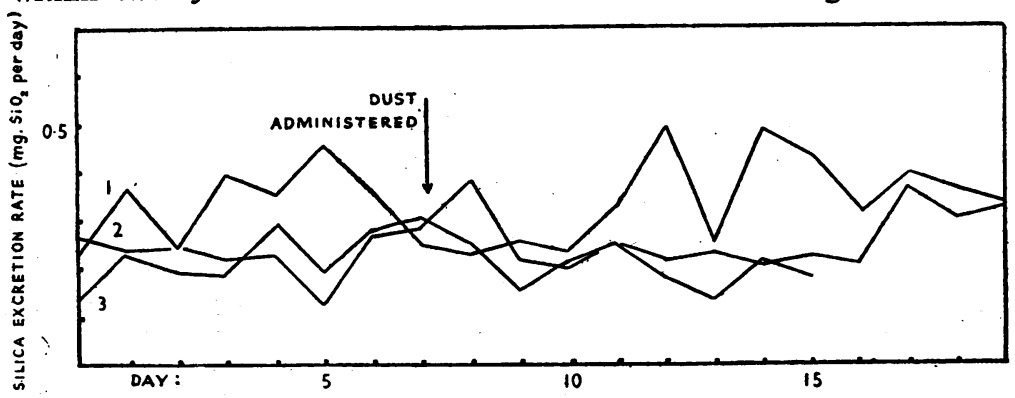

FIG. 4.-Effect of moulding sand and carborundum injected in oil suspension. 1, 2. moulding sand. 3. carborundum. normal three or four days after the injection. Five experiments, two of which are illustrated in Fig. 2, gave exactly the same type of curve. Similar graphs, of which two are shown in Fig. 3, were obtained when smaller quantities. of cement dust (equivalent to $3 \mathrm{mg}$. $\mathrm{SiO}_{2}$ ) were injected in saline suspension. This indicates that the solubility of the dust is not greatly affected by arachis oil.

When carborundum, mouldingsand, or-quartz dusts were injected into mice in quantities containing $4 \mathrm{mg}$. silica, no

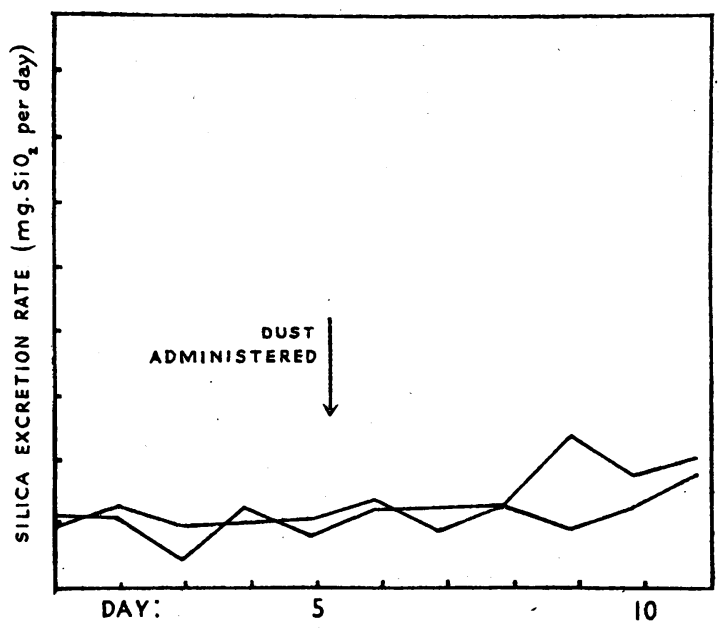

Fig. 5.-Effect of quartz, injected in oil suspension, on urinary silica excretion.

significant increase in the rate of silica excretion was detected. Typical excretion curves are shown in Figs. 4 and 5.

Tissue Analyses. - The silica contents of organs were compared fourteen days after the injection of the dusts. Experience has shown that this method is of little use in comparing the solubilities of dusts except when the differences are large, as there is often considerable variation in the quantities of silica found in the organs of mice which have received, as nearly as possible, 
TABLE 2

TISSUE SILICA OF CONTROL AND INJECTED MICE*

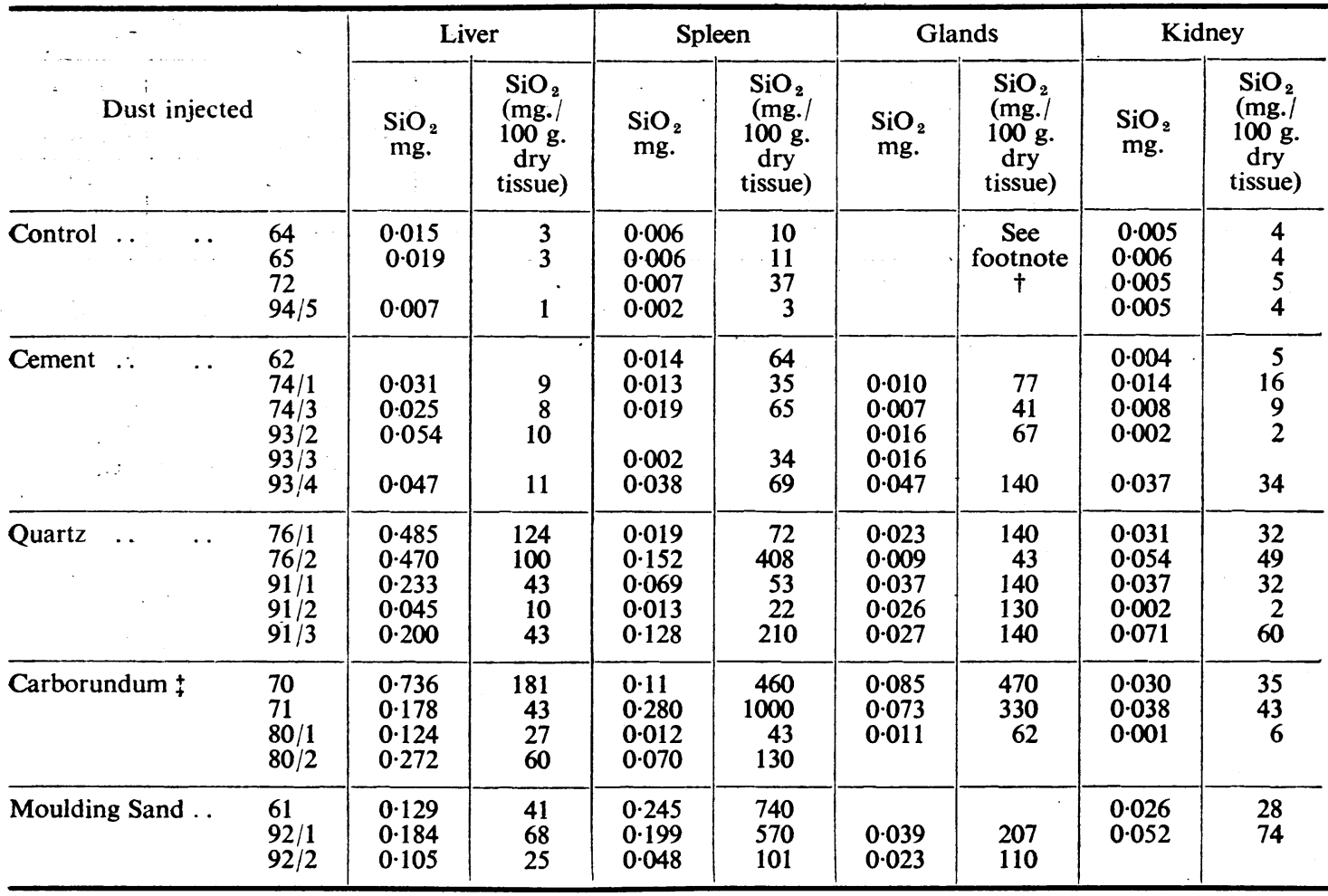

* Treated mice were killed fourteen days after injection.

$\dagger$ Normal glands contained $0.005 \mathrm{mg}$. SiO, $/ 100 \mathrm{~g}$. tissue, an amount too small for accurate estimation by the method used.

† Values are expressed as $\mathrm{SiO}_{2}$ for easy comparison; in fact the excess silicon is probably present as SiC.

identical treatment. However, the difference between cement and other dusts was so large as to give ample confirmation of the results obtained by urine analysis. The values obtained, which are also expressed as a percentage of the dry tissue weight, are given in Table 2. The tissues of a mouse normally contain a very small amount of silica, as is indicated by the analyses of tissues removed from untreated animals. After the injection of dust a sharp contrast is found between the silica contents of the livers of animals to which cement was administered and those of animals receiving the other siliceous dusts. In the former case the silica content of the organ is comparable with that of normal mice; in the latter, much higher values are found.

The analytical figures given for the spleen and lymph glands are much less regular. Those for cement are invariably low and comparable with normals, and those for other dusts are usually much higher, but the spleen and glands of a few mice receiving dusts other than cement are also low in silica. This variation may be due to the impossibility of injecting every mouse in exactly the same site. The silica-content of kidney tissue is always small but it may be significant that the values for injected mice are usually higher than those of the controls.

These analytical data suggest that much of the quartz, sand, and carborundum dusts is carried from the peritoneal cavity to be deposited mainly in the liver, spleen, and lymph glands. Probably cement is similarly carried to the liver before it is dissolved, since the tissues of animals killed four days after the injection of cement dust (Table 3, overleaf) gave much higher liver silica values than did those of mice killed fourteen days after injection. Whether the transport is affected by the oil which coats the particles must be determined by other experiments, but it is immaterial so far as the present investigation on solubility is concerned. Both tissue and urine analyses show that, compared with certain other dusts, the amount of silica which passes into 
TABLE 3

SILICA CONTENTS OF TISSUES FOUR DAYS AFTER THE INJECTION OF CEMENT DUST

\begin{tabular}{|c|c|c|c|c|c|c|c|c|c|}
\hline \multicolumn{2}{|c|}{ Liver } & \multicolumn{2}{|c|}{ Spleen } & \multicolumn{2}{|c|}{ Glands } & \multicolumn{2}{|c|}{ Kidney } & \multicolumn{2}{|c|}{ Lungs } \\
\hline $\begin{array}{l}\mathrm{SiO}_{2} \\
\text { Img. }\end{array}$ & $\begin{array}{c}\mathrm{SiO}_{2} \\
\mathrm{mg} \cdot / 100 \mathrm{~g} . \\
\text { dry tissue }\end{array}$ & $\mathrm{SiO}_{2} \mathrm{mg}$ & $\begin{array}{c}\mathrm{SiO}_{2} \\
\mathrm{mg} . / 100 \mathrm{~g} . \\
\text { dry tissue }\end{array}$ & $\mathrm{SiO}_{2} \mathrm{mg}$ & $\begin{array}{c}\mathrm{SiO}_{2} \\
\text { mg./100 g. } \\
\text { dry tissue }\end{array}$ & $\mathrm{SiO}_{2} \mathrm{mg}$ & $\begin{array}{c}\mathrm{SiO}_{2} \\
\text { mg./100g. } \\
\text { dry tissue }\end{array}$ & $\mathrm{SiO}_{2} \mathrm{mg}$ & $\begin{array}{c}\mathrm{SiO}_{2} \\
\mathrm{mg} . / 100 \mathrm{~g} . \\
\text { dry tissue }\end{array}$ \\
\hline $\begin{array}{l}0.110 \\
0.056 \\
0.244\end{array}$ & $\begin{array}{l}37 \\
21 \\
50\end{array}$ & $\begin{array}{l}0.016 \\
0.010 \\
0.016\end{array}$ & $\begin{array}{l}55 \\
67 \\
29\end{array}$ & $\begin{array}{l}0.045 \\
0.013 \\
0.050\end{array}$ & $\begin{array}{l}450 \\
120 \\
240\end{array}$ & $\begin{array}{l}0.009 \\
0.010 \\
0.010\end{array}$ & $\begin{array}{r}11 \\
12 \\
9\end{array}$ & $\begin{array}{l}0.008 \\
0.012 \\
0.016\end{array}$ & $\begin{array}{l}22 \\
34 \\
35\end{array}$ \\
\hline
\end{tabular}

solution when cement is acted upon by fluids in the body is considerable. Much of the silica is excreted, but, as in the experiments of King and others (1933), part is not recovered in the urine.

\section{Discussion}

The theory that tissue damage in silicosis is due to silicic acid produced by the solvent action of tissue fluid on inhaled dust particles has gained wide acceptance. However King (1945), who has presented much evidence in support of this theory, has also emphasized that a number of siliceous materials of relatively low solubility, such as certain sandstones, are toxic, and he was unable to find any marked difference in the solubilities of South Wales colliery dusts of known difference in pathogenicity. He has summarized evidence for and against the theory (King, 1947). Gardner (1938) noted the high solubility of the harmless silica condensate which forms in furnaces where sand is fused, and Smyth and Seaton (1940) have shown that the type of tissue damage which Gye and Purdy (1922) described as due to silicic acid is not produced in guinea-pigs or rats inhaling ethyl silicate vapour, which hydrolyses to silicic acid on the lung surface. It would seem that cement is another exception to the general rule that the more soluble dusts are the more toxic and that solution is a normal mechanism for the removal of this dust from the body, although this is contrary to the deductions previously made from the results of in vitro experiments (Briscoe and others, 1937). Judging from the results of these experimental methods, other siliceous dusts, both harmful and harmless, appear to have much lower solubilities in tissue fluid than cement, so that no generalization can be made. It does appear probable, however, that if the tissue-damaging property of the silicic acid is a main factor in the production of silicosis, other factors which reduce this action must be active in the case of certain dusts.

\section{Summary}

Moulding sand, quartz, carborundum, and cement dusts were injected intraperitoneally into mice. The silica excretion in the urine was increased to an appreciable extent only by cement. Tissue analyses confirmed this result, and suggest that cement has a relatively high solubility in body fluids.

The author is indebted to The British Iron and Steel Research Association for a grant towards the cost of the research and to Mrs. P. Palmer for technical assistance.

\section{REFERENCES}

Briscoe, H. V. A., Matthews, J. W., Holt, P. F., and Sanderson, P. M. (1937). Trans. Inst. Min. Met., 46, 270, 291.

Denny, J. J., Robson, W. D., and Irwin, D. A. (1937). Canad. med. Ass. J., 37, 1.

Emmons, R. C., and Wilcox, R. (1937). Amer. Mineralogist, 22, 256. Gardner, L. U.' (1923). Amer. Rev. Tuberc., 7, 344 (1938). Amer. Inst. Min. Met. Eng. Tech. Publ., No. 929. Gye, W. E., and Purdy, W. J. (1922). Brit. J. exp. Path., 3, 75 Holt, P. F. and Briscoe, H. V. A. (1949). Nature, 163, 334 Kettle, E. H. (1932). J. Path. Bact., 35, 395.

King, E. J. (1939). Biochem. J., 33, 944.

- (1947), Occup. Med., 4, 26. (1933). Biochem. J., 27, 1007.

二, Stantial, H., and Molan, M. (1938). Biochem. J., 32, 417 .

- , and McGeorge, M. (1938). Blochem. J., 32, 417. 27,

- (1945). Spec. Rep. Ser. Med. Res. Coun., London, No. 250.

Smyth, H. F., and Seaton, J. (1940). J. ind. Hyg. Tox., 22, 288 Whitehouse, A. G. R. (1937). Ibid., 19, 590.

(1938). Ibid., 20, 556. 